\title{
HABITAT'S OF INNOVATION IN THE KNOWLEDGE ECONOMY: A COMPARATIVE ANALYSIS OF TECHNOLOGY PARKS LOCATED IN THE NORTHEAST REGION OF BRAZIL
}

\author{
Ana Maria Magalhães Correia \\ Federal Rural University of the Semi-Arid, UFERSA, Brazil \\ E-mail: aninhamagalhaes25@gmail.com \\ Maria de Lourdes Barreto Gomes \\ Federal University of Paraíba, UFPB, Brazil \\ E-mail:marilu@ct.ufpb.br \\ Luciene Laranjeira Diniz \\ Federal University of Paraíba, UFPB, Brazil \\ E-mail: dinizlucy@hotmail.com \\ Submission: $29 / 04 / 2013$ \\ Revisions: 30/04/2013 \\ Accept: 13/05/2013
}

\section{ABSTRACT}

Technological advance has been the main driving force behind the developing regions, accounting for much of the increase in productivity, income, job creation and international competitiveness. In that sense, the Habitat's innovation, but specifically, the technological parks, undertakings promoters of the culture innovation, competitiveness, increase and business qualification, substantiated in the transference of knowledge and technology, with the objective of increase the output of wealth of a region. Thus, the objective this paper is to identify the potential to economic development and innovative place technology parks that are in operation in northeast Brazil. The results are derived from a qualitative research study, based on descriptive and exploratory research, which through a five case studies it was possible to obtain information about the topic. The finding indicates that the technology parks presents potentials that identify them, as inductors of the economic development and local innovation. Also, it presents limits that 
in spite of it they do not lessen the potential the localities of excellence for the transfer of technology based in technological base companies. It presents itself as difficulties that should be minimized or depending on the situation, solved through actions of the actors involved in behalf of the economic development and local innovation.

Keywords: Economic Development. Local Development. Technological Innovation. Technological Parks.

\section{INTRODUCTION}

The current dynamics of the economic scene has increased the complexity of companies, and the competitiveness between them, since many transformations are happening in the environmental, social, economic and political spheres, with phenomena such as capitalist restructuring, globalization and technological development (VASCONCELOS et al. 2009). Such phenomena have emphasized people and their intellectual abilities, given the search for competitive edge in this new context. The use of this strategy has become a resource of differential strategic value, which led to the emergence of organizations based on information and knowledge.

Thus, the emergence of dynamic industries, with productive processes based on the intensive use of new technologies of automation, represents, according to Alvim and Castro (2005), a new paradigm for the organization of productive activities, and for labor relations, with reduced jobs in the direct production process, smaller salaries, and growth in service industries.

Hauser, Zen, and Lopes (2004) assert that one of the main traits of this new productive profile is the tendency towards what they call "dematerialization of production," which implies a increasingly smaller consumption of energy and raw materials, smaller spaces, and the necessity of boost and dissemination of knowledge and innovation.

From the perspective of Hauser, Paladino, and Medeiros (1997), innovative environment is the system of social, institutional, organizational, economical, and territorial structures that creates the necessary conditions for the continuous generation of synergies, and its transformation, in a productive process originated from this synergetic capacity. 
The implementation of local systems of innovation - organizations directed to developing activities based on new technologies are being used as an instrument for the local and/or regional economic development. They possess distinct nomenclatures, depending on aspects such as location, cooperation between companies and universities, administrative notion, insertion in the enterprise, and insertion in the city and region (ALVIM and CASTRO, 2005).

In the face of this evidence, Stainsack (2003) claims that technology parks are generally characterized as companies reunited in a common location, and tied to a university campus - within its space or next to it. In these enterprises, there is an administrative and coordinative entity responsible for facilitating the integration between university and companies, and for managing the usage of the existing installations.

Thus, in order to foster the local innovative and economic development, Albuquerque (2004) says that it is indispensable to formulate mixed policies in which the measurements taken to achieve the main macro-economic balances are accompanied by actions that aim to foment existing potentialities in each territory. In this task, both the regional and the local governments must play a decisive role in encouraging and facilitating the creation of business development opportunities.

Therefore, since we consider technology parks as relevant for the development of the local conjecture, the focus of this research is to analyze the potentialities for the local economic and innovative development of technology parks that function in the Northeast region of Brazil, as well as their strategic actions to continue stimulating and supporting the creation of micro and small technologybased companies, fulfilling their mission of promoting the generation of work and income, and economic and innovative development, as well as the improvement of the region's quality of life.

\section{LITERATURE REVIEW}

\subsection{Economic Development}

The idea of economic development was part of early economic studies. Souza, (2005) states that some Economists have addressed this issue, especially Joseph A. Schumpeter. Schumpeter has become a pioneer in the analysis of the development of technical progress and its effects on the economy. He contributed 
significantly to a better understanding of economic development and its evolution over time.

In that sense, Schumpeter (1997) analyses deeply the whole process of development and technological innovation. His theory has been taken as a basis for the development of studies about innovation. His evolutionary theory points out that innovation is conceptualized from five elements: the introduction of new products, new processes, new industrial organization, access to new markets and obtaining new raw materials (CARRARO; FONSECA 2008).

According to the authors afore mentioned, the organization of production, the combination of new inputs and the endless search for new products have proved fundamental in generating economic development. These functions are essential; not only for the innovative entrepreneur, but also for a network of agencies and institutions that would be created with the primary goal of adding to the economic system the appropriate incentives. Thus, businesses should challenge themselves continually in search of new development, not only as personal goals, but as a matter of survival.

Therefore, in consonance with Schumpeter (1997), the company, in order to remain in this system must always be innovative. As the main agent of the capitalist mode of accumulation, businesses are constantly changing, whether with products, processes or industrial organization. These changes are conceptualized as a process by Schumpeter called "creative destruction" which refers to this constant change or, according to the author, "... revolutionizes the economic structure from within, constantly destroying the old, and creating the new".

Carraro and Fonseca (2008) state that, nowadays, neo-Schumpeterians argue that innovation does not happen at random. It is a result of a process of searching, trial and imitation. Dosi (1998), states that innovation is the center of the corporate growth and the generation of pure profit, depending on the demand and supply. Probing the market, the entrepreneur finds out what the targeted public wants to consume and generates new products, improves existing ones and adopt $s$ more efficient processes. For instance, technologies create new needs, leading to the demand for better products or the improvement and or upgrading of existing products. 
Two basic forces of inductive technology are proposed by Schmookler (1996). The first points to the needs revealed by users and consumers (Demand-pull). Thus, the market demand $s$ (existing or projected) applies pressure on companies, which, in turn, pressure their engineers for new technological results that, in turn, demanded and demand the carrying out scientific research.

And the second factor defines technology as a standalone or nearly autonomous, derived from the advances of science (Technology-push). This paradigm assumes that the scientific results obtained in laboratories, leads to technological innovation and the generation of products with potential for market insertion.

Campos and Valadares (2013), call attention to the fact that neither the paradigm of Technology-push nor Demand pull are enough to model the complex relationships between these variables in developed economies, where research and development are transformed into macro economical results. There are rich feedback processes between producers and consumers of technology. It involves the industry the market and academic institutions. The challenge here is to balance both sides of this equation, keeping in mind that the economic growth, generated by technological innovation, produces additional resources both for basic researchessential to the advancement of human knowledge - and for applied research, providing feedback throughout the process, allowing the spiral of sustained growth reflecting on improving local conditions.

It is Technology-push (in which scientific resources are introduced and it is expected the self-governing of scientific processes) and Demand-pull (in which the market define the lines of research and innovation), that leads to identify a tendency to consider the impact on social development, which is simply produced from the impact on economic development, based on the concept of technological innovation.

Tigre (2006) adds that in advanced countries, the efforts of R\&D performed by Universities and Research Centers may eventually result in innovations driven by technology. In developing countries, where the ability to generate scientific technologies is more limited and the capacity and autonomy of the companies to make radical innovations is lower, the demand is the main stimulus for innovation. The diffusion of technology, especially in less developed countries, requires a series of adaptations to the circumstances of the local market, based on income levels, 
weather conditions, consumer habits, business scale and availability of inputs and materials.

According to what has been exposed so far, an approach to development based on localities proved to be an effective possibility to the activities who targeted local economic development, due to the prospects that the investments in the productive sectors have brought to regional economies. This is the central point of the new theory of local development, in which the interaction with different local agents (entrepreneurs, universities, government, research agencies, promotion and development of credit) empowers the community to face competition from large global companies and creates conditions for economic growth.

In that sense, a new vision of development favors local levels through local development, which Franco (2000) calls self-sustained strand in which the local processing element, acts as a promoter of social-political-economic changes representing a favorable environment for the exercise of new practices and development policies.

\subsection{Local Development}

According to Abramovay (1998), the idea of local development emphasizes on specific institutional mechanisms capable of mobilizing productive energies that end up being inhibited by the functioning of some markets and the mere presence of some infra structures prove unable to awaken.

Understanding that the concept of place is not within the physical limits, but in the economic base that defines their specialty, and it can be settled in relatively small spaces such as a street or large as a state or country. The location can be defined by a location (city, street or neighborhood) region or nation that constitutes a subspace involving a territorial clipping which is expressed in economic, political and social terms (ALBAGLI, 1999).

Undoubtedly, the political and administrative support provided by local authorities and the conviction in the role to play in supporting economic territories are decisive factors in these local development initiatives. In addition to this support, it is also fundamental the articulation between local socioeconomic agents as business associations, financial institutions, advisory centers, universities and R\&D institutions, among others (LLORENS, 2001). 
In this context, Buarque (2002) states that any strategy to promote local development must be structured in at least three major pillars: organization of society, contributing to the formation of local social capital (understood as organizational capacity and cooperation by local society) combined with the formation of institutional spaces of negotiation and management, adding value to the supply chain, with the addition of the competitiveness in economic activities with local advantages as well as restructuring and modernization of local public sector, as a way of decentralizing decisions and to increase efficiency and effectiveness of local public administration.

Thus, local development represents a transformation in the economic base and social organization at the local level, resulting from the mobilization of the energies of society, exploring their specific abilities and potential. The development should increase social opportunities, the viability and competitiveness of the local economy, generating a source of income and wealth, combined with innovative initiatives and mobilization of the community, linking local potential conditions of the region to which it is inserted (BUARQUE, 2002).

Diniz (2001) states that in addition to these attributes, the search effort and the competitive struggle, centered in the innovative process depends on two dimensions: business capacity to promote research and development and identify new products or processes that ensure economic success (productive and commercial) of the companies and the local capacity to learn, in order to create an atmosphere of change and progress, in Asheim (1996) called learning regions and Keeble et al. (1998) collective learning.

It is based on the idea that innovation is the core engine of economic development and the acknowledgement that the regions have their own attributes, summarized as social immersion (embeddedeness) relational assets or non-traded interdependencies that economic success depends on the existence of innovative means (ALBAGLI, 1999). It comes to the discussion of the role of Habitat's innovation as a result of the combination of research, development and its interaction with the social and economic conditions through the interaction between business and the environment in which they are involved. 


\section{METHODOLOGICAL PROCEDURES}

This research has a descriptive and exploratory component. The main discussion was based on five case studies, in which we gathered information about the subject in question within the context of technology parks located in the Northeast region of Brazil. Such information served as the foundation of this article.

In order to achieve the objective of this study, we developed a research methodology in which the dimensions, variables, and its respective indicators were used as measurement tools. Regarding this, Lakatos and Marconi (2001) assert that a variable can be considered as: a classification or a measurement; a quantity that varies; an operational concept that contains or represents values; aspects, properties or factors that can be discerned and measured in a study subject.

Hence, for the development of this article, we have taken into consideration only one independent dimension (main component) to approach the essential questions that this study tries to answer, with their correspondent variables and indicators that explain the data variation, and facilitate the interpretation and simplification of the final analysis, according to the Chart 01 below:

\section{SIZE: TECHNOLOGY PARK}

Economic development is complex and designed to promote local technological knowledge-based economies through the integration of scientific and technological research, with technology intensive companies and government organizations.

\begin{tabular}{|c|c|}
\hline VARIABLES & INDICATORS \\
\hline $\begin{array}{l}\text { Economic development and Local } \\
\text { Development }\end{array}$ & $\begin{array}{l}\text { - Support services to management of } \\
\text { technology park; } \\
\text { - } \quad \text { Region's performance and profile; } \\
\text { - } \quad \text { City and region image ability; } \\
\text { - Infrastructure support to local } \\
\text { development; } \\
\text { - Support local financial, industrial, } \\
\text { services and hinged to the S\&T Park; } \\
\text { - Identification and characterization of } \\
\text { innovative activities and opportunities. }\end{array}$ \\
\hline
\end{tabular}

Chart 01: Variables investigated.

Source: Author's (2009/2010).

The research technique employed in this work, according to the objectives, involved the following steps: data gathering through the application of a questionnaire, interview, data quantification, and processing and analysis of the collected data. 
We gathered the primary information by applying a structured questionnaire with one main approache - economic development. To analyze them in this study, the instrument was divided in two parts:

- Part 1: Characterization of the technology park;

- Part 2: Economic development and local development;

- Part 3: Innovative activities.

Part 2 of the questionnaire, which contains topics related to economic development and local development, used a Likert scale to measure the opinion of the researched targets. The questions about qualitative declarations are resultant of research data comprehension mapping. The level of agreement of the questionnaires with regard to the investigated factors was numbered using a scale composed by five equidistant points, with "1" and "2" corresponding to discordance or dissatisfaction, "3" equivalent to neutrality or indifference, which can be considered impartial or negative, and "4" and " 5 " meaning the level of concordance or satisfaction.

For the execution of the research, the data was organized, selected, and put aside in similar groups according to the desired objectives of each research variable, in order to facilitate the examination and interpretation of the results.

In general, the data analysis is a process that involves many procedures and statistical analysis that requires data interpretation. This interpretation aims to establish the connection between the obtained results and other results from theories or previous studies (GIL, 2006).

\section{RESULTS PRESENTATION AND ANALYSIS}

This topic demonstrates the results of the research, applying the techniques specified in the methodology section, with inferences based on the primary and secondary data, alongside the research form, semi-structured interviews, and inventory of the obtained results with its respective theoretical references. For better comprehension, this chapter is divided into two topics: the first describes the technology parks, and the second presents the potentialities for the local economic and innovative development, focusing on the items addressed in the questionnaire, and in the semi-structured interview. 


\subsection{Description of the technology parks}

To describe the technology parks in this investigation, general information was obtained from the semi-structured interview, as well as from the material offered by the administrators of each organization.

\subsection{1}

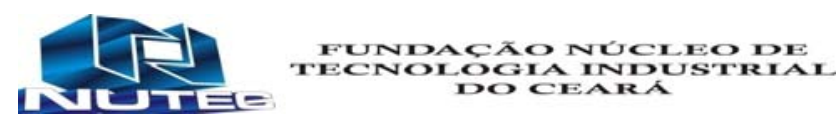

NUTEC, that began its activities in 1979 tied to the Department of Science, Technology, and Superior Education (SECITECE), has the following mission: "To seek technological solutions for a sustainable industrial development that benefits society". To achieve its institutional goal, the technology park has 17 laboratories in the following areas: soil treatment and corrosion, sanitizing products and cosmetics, environmental chemistry, biofuels, textile, automobile safety, electrical measurements and civil construction, rock revetments and ceramic processes, food analysis and certification. It also has an incubator for technology-based companies - PARTEC; a quality management system certifier - NUTEC CERT; and Núcleo de Apoio à Exportação (Exportation Support Center), to endorse companies from the State of Ceará, via PROGEX, with the support of Financiadora de Estudos e Projetos (Studies and Projects Financer) - FINEP and NUTEC EXPORT.

\subsection{2}

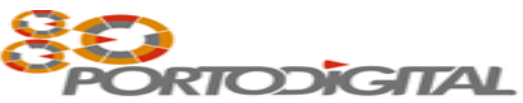

Porto Digital was launched in December 2000, and in mid-2001 it already had assembled 12 Information and Communication Technology companies, with 194 employees. In 2008, the number of organizations increased to 107, including ten from other regions of Brazil, four multinationals, and four technology centers. Together, these companies currently have about 3.700 collaborators, which represents a growth of roughly $1,700 \%$ in seven years, attesting to the APL evolution, the good number of jobs created, and the importance of the arrangement in absorbing the State's human capital of Information and Communication Technology. In this aspect, Porto Digital is the result of an environment of innovation consolidated in Pernambuco in the last decades with coordinated efforts of the university, the productive sector, and the government, intending to put the Information and Communication Technology industry in the economic core of the State of 
Pernambuco. This sector has great growth potential and is also the foundation for the region to be more competitive in any contemporary economic development strategy.

\subsection{3}

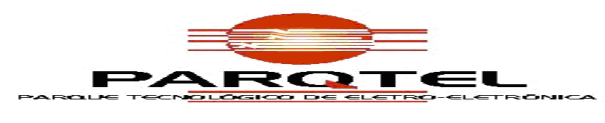

ParqTel was created over ten years ago by the Pernambuco government to congregate technology-based enterprises of electrical and electronic sectors. Apart from reuniting these enterprises, the technology park has the goal of developing $P \& D$, creating innovative products and services in its area, promoting economic and social development within the State, and reuniting technology-based companies to create innovative products and services. Besides the industries of materials, electric and electronic devices, and industrial automation, it also comprises sectors such as medical equipments industry, software sector, and "future carrier" technologies, such as optoelectronic, nanotechnology, and biotechnology.

\subsection{4}
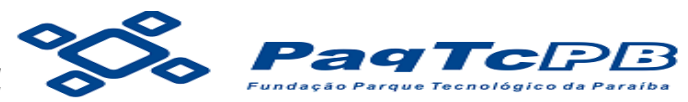

"Promoting the innovative entrepreneurship within the State of Paraíba, supporting the creation and the progress of technology-based companies and social enterprises, through the appropriation of knowledge and technologies generated in the P\&D organizations, and the insertion of products, services, and processes in the market - including abroad - contributing to the development of the country": this is the mission of PaqTcPB. Created in 1984 as one of the first four technology parks in the country, Fundação Parque Tecnológico da Paraíba is a non-profit organization that encourages scientific and technologic progress, and the promotion of innovative entrepreneurship in Paraíba. By promoting articulation among its partners, knowledge chains and productive activities, the institution seeks to new ways of attracting and fixating competencies in the State.

\subsection{5}

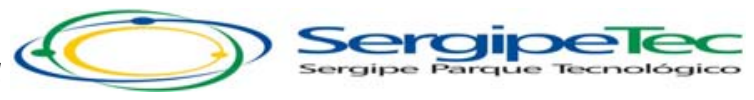

Sergipe Parque Tecnológico is a non-profit private association, recognized as a State Social Organization. Its temporary headquarters currently has more than 25 companies, three company incubators and eight research institutions, generating more than 300 jobs. It is one of the main agents that attract investments in oil, gas, 
and renewable energies to Sergipe. Its mission is to promote entrepreneurship, seeking innovation, competitiveness, and generation of knowledge, work and income for the State. It operates as a link for private entrepreneurs to answer the demands of the market; for the public power to the State's economic, social and technological development; for the academy to produce researches and transfer results to society and market. It is part of a local system of innovation and knowledge that aims to systematize the actions of science, technology and innovation policies in the State.

\subsection{Potentialities for the local economic and innovative development}

The information about technology parks economic and local development was divided in regional profile and innovative activities. About this, Zouain e Plonski (2006) say that this indicates the technology parks contribution to regional development, stimulating the local economic activity by creating and rapidly developing companies, increasing commercial and exportation activities based on products and services of high aggregated value, and generating job opportunities and income for qualified professionals.

The regional profile is presented in two degrees of comprehension with regard to the level of agreement of the technology parks researched. On one side, we have answers about the profiles of companies, institutions, and conglomerates able of generating knowledge, technology, and information in connection with the technology parks disseminated in the region; and, on the other hand, there are answers about the existing conditions for local economic development, with the presence of favorable conditions for the companies installed in the technology parks.

About the profiles of companies, institutions, and conglomerates, we can see, according to Table 1, that most of the technology parks, including NUTEC, Porto Digital, PaqTcPB, and SergipeTec, agree that, in the region where they're inserted, there are companies in the same field of the technology parks, diversity in the region's industrial structure, possibility of institutional support from alliance networks favoring the parks, institutions able to stimulate the flow of knowledge and technology between the parts involved, agglomeration of companies involved with the technology offered by the research institutions, and work force with medium and superior education in the area. 
Table 1: Region Profile

\begin{tabular}{|c|c|c|}
\hline \multirow[b]{2}{*}{ Region Profile } & \multicolumn{2}{|c|}{ Degree of Agreement } \\
\hline & Average & Classification \\
\hline $\begin{array}{l}\text { There is presence of peer group in the park's operational } \\
\text { actions }\end{array}$ & 4 & Agree \\
\hline $\begin{array}{l}\text { There is diversity of industrial structure in the region } \\
\text { (presence of companies from different segments) }\end{array}$ & 4 & Agree \\
\hline There are local presence of large companies & 3 & $\begin{array}{l}\text { Neither Agree } \\
\text { Nor Disagree }\end{array}$ \\
\hline $\begin{array}{l}\text { There is presence of innovative companies that produce } \\
\text { products } \\
\text { and technological services of high added value locally }\end{array}$ & 5 & Totally agree \\
\hline $\begin{array}{l}\text { There is the possibility of institutional support networks } \\
\text { alliances in the park's favor }\end{array}$ & 4 & Agree \\
\hline $\begin{array}{l}\text { There are institutions that can stimulate and manage the flow of } \\
\text { knowledge and technology between research institutions, } \\
\text { companies and markets }\end{array}$ & 4 & Agree \\
\hline There are low transaction costs in the region & 3 & $\begin{array}{l}\text { Neither Agree } \\
\text { Nor Disagree }\end{array}$ \\
\hline $\begin{array}{l}\text { There are cluster of firms directly involved with technology } \\
\text { provided by research institutions }\end{array}$ & 4 & Agree \\
\hline There is availability of local skilled labor (higher level) & 4 & Agree \\
\hline There is availability of local skilled labor (middle level) & 4 & Agree \\
\hline Average & 3 & $\begin{array}{l}\text { Neither Agree } \\
\text { Nor Disagree }\end{array}$ \\
\hline
\end{tabular}

Source: Direct Research, 2009/2010.

This degree of agreement is evidenced specifically by each technology park. NUTEC tells that it is the result of an environment that stimulates the creation and development of companies and products, specially the knowledge innovative and intensive ones. This environment offers to emerging companies and research teams' elements such as physical area and infrastructure, companies in the same field, and services to support and create synergy within and outside the enterprises. It also potentializes the process of creating, attracting, and fortifying local and regional innovative companies, particularly developing those economic sectors with growth vocation and potential.

Porto Digital, that has the mission of becoming one of the main actors in Pernambuco's economy, says that the regional profile of the companies, institutions, and conglomerates increases the technology information pole interaction with other productive sectors of the State, strengthening the competitive edge of the companies installed in the technology park. In this sense, it is considered a valuable asset for the State, with the potential to contribute to the development of the efficiency patterns and competitiveness levels of all economic sectors, because of ICTs transversal 
characteristic. As such, Porto Digital aims to promote the exchange of knowledge and information/communication technology innovation solutions generated in the environment for other productive chains in the State of Pernambuco, with the intention of promoting integration between productive chains, guaranteeing their condensation, as well as the ICT's itself.

PaqTcPB tells us that it is a non-profit organization that seeks to achieve scientific and technologic development, and to promote innovative entrepreneurship in Paraíba. It was by promoting the articulation between partners, and between the many knowledge chains and productive activities, that the institution has searched for new ways of attracting and fixating competencies in the State. That is, each year new business projects are accompanied, which augments their chances of growing with the technical and managerial support accessible to each company.

SergipeTec says that, according to this assertive, it attracts technology-based companies aiming to establish them in the park, through activities of divulging and promoting; stimulates the entrepreneurship of technology base in the State, favoring the creation and development of new companies, according to the incubator model; and promotes the integration of the scientific community with companies and market, aiming to create a complete cycle for developing technology-based products and services.

Allied to this resulted, there's the technology parks agreement that there is work power with medium and superior education levels in the region. In this sense, NUTEC, Porto Digital, PaqTCPB, and SergipeTec all possess the same opinion, that it is necessary to have professionals that fulfill the market's demands and are up-todate with the tools and methodologies necessary to optimizing the productive processes of technology-based companies.

It is important to stress that ParqTel disagreed with all this information about the profile of companies, institutions, and conglomerates, justifying that it is currently, according to its manager, an unfinished/interrupted project, because, among other factors, of changes in the State's government orientation in the administrative term.

Oliveira (2003) and Joyal (2002) say that this result about the profile of companies, institutions, and agglomerations, as well as the existence of qualified work force, brings up the main characteristic of the technology parks administration, 
which is stimulating the formation of new companies in cutting-edge sectors, and the attraction of companies specialized in advanced technologies; revitalizing traditional regional industrial sectors by incorporating the region and new technologies; promoting the business vocation and qualified work of the region; and favoring the region's technological independence by internally generating new advancements and technologic applications.

Add to this the statement from Buarque (2002), who says that the promotion of the local development must be structured in at least three pillars: society organization, which contributes to forming the local social capital (i.e., the local society's organization and cooperation capacity) combined with the formation of institutional spaces for negotiating and administrating; value aggregation in the productive chain, with the articulation and augmentation of the economic activities competitiveness with local advantages, and the restructuration and modernization of the local public sector as a way of decentralizing the decisions and elevating the efficiency and efficacy of the local public management. All this associated with some form of distribution of social assets, particularly knowledge, expressed by education and technologic capacitance. Therefore, changes are a result of these three processes, and the resultant synergy in the social sphere makes the local development in a solid and consistent fashion possible.

About the existing conditions for the local economic development, we can see that, according to Table 1, there's general neutrality, i.e., the technology parks do not agree nor disagree about the presence of large enterprises, with the exception of Porto Digital, that says that the region is mostly composed by small and medium companies. However, multinationals such as Motorola, IBM, and Microsoft are also present in the region with their regional offices (Motorola and Samsung actually have partnership agreements with C.E.S.A.R for developing softwares for mobile phones). And there are low transaction costs in the region.

With this result, we can see that, with few exceptions, the regional profile with regard to the existing conditions for the local economic development leaves much to be desired in the technology parks researched, as well as in their installed companies, independently of the positive performances shown. Thus, Brazil's Northeast region as a whole, in which the technology parks are installed, makes it 
impossible for a general satisfactory result regarding the regional profile of the parks researched.

This can be verified with the statement of Galvão and Vergolino (2009) about the Northeast region. They assert that, throughout the 1990s, the effects of the commercial opening for the Brazilian regional development have been very distinct. In the Northeast, with the possibility of importation, the introduction of new technologies in intensive work force industries, and the production of better quality products, were necessary conditions to avoid more and more the technological distance from the Central-South regions of Brazil.

However, we must say that the Northeast region is still relatively behind when compared to the South and Southeast regions of Brazil, despite of the differentiated growth experienced in some expansion areas. This regional inequality is resultant of the different productive structures of each region, and the processes by which they are integrated to the national and international markets. The way in which this process occurs reflects in the Brut Intern Product (BIP) division between Brazil's regions, which can bring huge difficulties for the States performances in trying to diminish regional differences.

Hence, Sicsú and Lima (2003) asseverate that it is important to strategically reflect about the possible emergence of a new development pattern with innovation and value aggregation, reducing the distance that still separates the Northeast region from the national average. In this sense, the S\&T dimension and innovation are indispensable, and must play a central role in the development process alongside a number of other strategic factors.

As a result, the consolidation of the Northeast region in a structured segment of science, and specially technology, can give support to strategic sectors of the economy and be a great attractive of new segments for the regional production and service provision sceneries, which consists in a great opportunity to promote the dialogue between private initiative and public power in order to develop the region. To be exact, captivating the interest in acting in projects that generate revenue and are perfectly integrated with the urban planning (infrastructure of transportation, telecommunications, commerce, industry, housing, and services in general) for the regions in which they are inserted. 
It's in this context that the technology parks constitute an important alternative for the local economic and innovative development, since, according to the results seen so far, they reunited conditions to identify regional economic potentialities and contribute to the technologic innovation, where innovative companies or knowledge intense ones can be delimitated or, according to more innovative tendencies, widespread in the region.

Innovative activities in incubated and/or installed companies in the technology parks are identified in degrees of importance of internal and external R\&D activity, acquisition of other external knowledge, software acquisition, acquisition of machinery and equipment, and introduction of technology innovations in the market, according to Table 2 that follows:

Table 2: Innovative activities

\begin{tabular}{|c|c|c|}
\hline \multirow[b]{2}{*}{ Innovative activities } & \multicolumn{2}{|c|}{ Technology Park } \\
\hline & $\mathrm{n}$ & $\%$ \\
\hline \multicolumn{3}{|l|}{$\begin{array}{l}\text { Importance of internal P \& D through business incubated and / or } \\
\text { installed so far held }\end{array}$} \\
\hline High & 4 & 80 \\
\hline Average & 1 & 20 \\
\hline \multicolumn{3}{|l|}{$\begin{array}{l}\text { Importance of acquiring external R\&D through business incubated } \\
\text { and/or installed so far held }\end{array}$} \\
\hline High & 2 & 40 \\
\hline Average & 3 & 60 \\
\hline \multicolumn{3}{|l|}{$\begin{array}{l}\text { Importance of acquiring external knowledge through of the } \\
\text { incubated companies and / or installed, held so far }\end{array}$} \\
\hline High & 2 & 40 \\
\hline Average & 3 & 60 \\
\hline \multicolumn{3}{|l|}{$\begin{array}{l}\text { Importance of acquiring software through business incubated and / } \\
\text { or installed, held so far }\end{array}$} \\
\hline High & 2 & 40 \\
\hline Average & 2 & 40 \\
\hline Low & 1 & 20 \\
\hline \multicolumn{3}{|l|}{$\begin{array}{l}\text { Importance of acquiring machinery and equipment through the } \\
\text { incubated and / or installed, held so far }\end{array}$} \\
\hline High & 4 & 80 \\
\hline Average & 1 & 20 \\
\hline \multicolumn{3}{|l|}{$\begin{array}{l}\text { Importance of the introduction of technological innovations in the } \\
\text { market through business incubation and / or installed to date }\end{array}$} \\
\hline High & 4 & 80 \\
\hline Average & 1 & 20 \\
\hline
\end{tabular}

Source: Direct Research, 2009/2010.

About the importance of internal and external R\&D activity, the biggest emphasis is in the internal activity, according to Table 2, with most technology parks, among them NUTEC, Porto Digital, PaqTcPB, and SergipeTec, agreeing that the importance of these activities is high for the development of innovative activities in 
the incubated and/or installed companies. And the external activity has medium importance among the incubated and/or installed companies of NUTEC, ParqTel, and SegipeTec. It is important to point out that the technology parks administrators were asked to give a description of the internal and external P\&D activities, but this item was not answered because of limitations in obtaining more detailed information from incubated and/or installed companies, despite the fact that their commitment to giving biannual general data about their programs, projects and activities' performances.

This result highlights what Kim and Nelson (2005), and Ortt and Smits (2006) affirm about two models of technologic innovation: linear and interactive, introducing knowledge as a dynamic and inter-current element in all phases of the process, and considering that technology innovation in incubated and/or installed companies in the technology parks are not related only to invention, production, and commerce, but to a continuous social process involving activities of management, coordination, apprenticeship, negotiation, investigation of the users' needs, acquisition of competences, managing the development of new products, financial management, etc. Tidd, Bessant, and Pavitt (2008) complement saying that, in practice, innovation constitutes a process of parity and adjustment that sometimes takes the pulled form, and sometimes, the pushed one, and requires, thus, a successful innovation, i.e., an interaction between internal and external R\&D activities.

ParqTel considers medium the importance of the internal and external R\&D activity, because, according to its administrator, since the park does not have incubated companies, innovative activities are developed by each company individually and in isolation; despite that, its companies incorporate the R\&D process as a tool for obtaining innovative and commercially competitive products and processes. And in the external R\&D activity, they have a partnership deal with Porto Digital for developing technologies in the urban mobility area, with the automobile chip.

According to this reasoning, in conformity with external R\&D activity, the acquisition of other external knowledge has a medium degree of importance among the incubated and/or installed companies at NUTEC, ParqTel, and SegipeTec, as we can see in Table 2. This way, according to Takashi and Takashi (2007), new ideas, products, and processes converted in innovative activity can emerge from 
challenges, natural or provoked, of the organizations internal and external environment, and must be canalized properly, so that they result in the improvement of methods, routines, and organization, i.e., the essence of fast processes in technology development (BIANCHI, et al. 2010).

About the importance of software acquisition, Table 2 shows that Porto Digital and PaqTCPB consider high the importance of this acquisition, ParqTel and SergipeTec consider it medium, and only NUTEC attributes a low degree of importance to it. This result is justified by the incubated and/or installed companies' preoccupation in observing software consumer market tendencies, perceiving the receptivity of products and services offered, and identifying innovation opportunities, as well as concerning about adjusting to the performance area of the park in which it is inserted. According to the administrators of Porto Digital and PaqTcPB, that consider high the importance of software acquisition, we can highlight among the ICT segments the production of management softwares, solutions for financial and health systems, games, security sector softwares, administration systems for traffic and transportation, software usability, and integrated solutions for portal development, extranets and intranets.

About the importance of acquisition of machinery and equipments, according to Table 2, most technology parks, among them NUTEC, Porto Digital, PaqTcPB, and SergipeTec, affirm that the acquisition of machinery and equipments is high for the development of innovative activities in incubated and/or installed companies, proportionating a functional and well-equipped environment. In this sense, the innovation process is also determined by the ability of coordinating these technical resources, with the objective of supporting the generation of new ideas to improve products and processes, and creating new knowledge. ParqTel does not share this opinion, because, according to its administrator, the importance of this acquisition is medium, since the installed companies already possess the machinery and equipments necessary for the execution of their activities, and it is not necessary more investments in this aspect.

About the importance of the introduction of technologic innovations in the market, most technology parks, among them NUTEC, Porto Digital, PaqTcPB, and SergipeTec, attributed a high degree of importance to introducing new technologies in the market by the incubated and/or installed companies; only ParqTel informed 
that this importance is medium, according to Table 2. This result has two justifications: the first one is from the point of view of the park itself, that admits in its environment essentially technology-based companies; and the second one, from the perspective of the incubated and/or installed companies themselves, in which the dynamic of the technologic innovation process depends, according to Ferguson and Olofsson (2004), and Hindle and Yencken (2004), more on the knowledge learning processes tied to interactions between organizations and agents, allowing the generation, reproduction and retro-feeding of learning processes and their conversion into innovative activities.

Generally speaking, this result is verified according to the assertion of Tid, Bessant, and Pavitt (2008) about technologic innovation. According to them, the success in introducing technology innovations by incubated and/or installed companies at technology parks consists in its management, which consists in the perception of internal and external environment, strategic selection of potential innovations to be developed, use of resources available for the innovation to be developed and implemented, and reflection as a way of contributing to the apprenticeship through the experience. Chiaroni, Chiesa, and Frattini (2010) also say that it is in the introduction of technologic innovations in the market that companies will discover the business models more suited for commercializing the technology. In other words, it is the practice of establishing relations with the external environment that one commercially identifies the innovation opportunities.

\section{CONCLUSIONS}

Technology parks are innovative environments. As such, instruments implanted in development and developing countries make regional and national economies more dynamic, adding knowledge and technology innovation to them. In this research scenery, we noticed that all five studied parks promote the innovation, competitiveness, and business capacitance growth culture, based on the transference of knowledge and technology via interaction among its actors in the environment in which they are inserted.

Generally speaking, the research results show that there are potentialities for the local economic and innovative development of the studied technology parks. This result is based in two groups of specific questions (characterization of the technology 
parks and local and economic development). The whole analysis performed in this article ensures that the objective was reached throughout the research, in which we demonstrated the potentialities for the local economic and innovative development.

Hence, it is noticeable that the five technology parks studied are important environments, propitious to the innovation that promotes economic and innovative development in the region in which they are inserted. And, despite having some limitations, they guarantee support and have basic conditions for the emergence of enterprises based in new technologies that, as such, must make possible many connections with the involved actors in order to contribute to the development of the technology park as whole.

Although this study proportionates an analysis of the potentialities for the local economic and innovative development of technology parks located in the Northeast region, results found do not generalize the current situation of the operating Brazilian technology parks, nor generalize questions concerning the local economic and innovative development of these enterprises, because, apart from studying just five cases, the research was restricted to the Northeast region, which, according to what has been said before, is the least favored with regard to the consolidation of innovation habitats if compared to the South and Southeast regions of the country. However, this study brings important contributions in the legal, socio-economical, and institutional spheres to the study of the technology parks operating in the Northeast region, since until now no specific research had been produced about all these enterprises.

\section{REFERENCES}

ABRAMOVAY, R. A formação de capital social para o desenvolvimento local sustentável. Anais... II Fórum CONTAG de Cooperação Técnica. São Luiz, 1998.

ALBAGLI, S. Globalização e espacialidade: o novo papel do local. In: CASSIOLATO, J. E.; LASTRES, H. M. M. (Org.). Globalização e inovação localizada: experiências de sistemas locais no Mercosul. Brasília: IBICT/MCT, 1999.

ALBUQUERQUE, E. M. Apresentação. Revista Brasileira de Inovação, v. 3, n. 1, 228 p., jan/jul. Rio de Janeiro: FINEP, 2004.

ALVIM, A. A. T. B.; CASTRO, L. G. R. Arranjos produtivos locais e recuperação de áreas urbanas: os casos de Porto Alegre e Recife, Brasil. Anais... XI Seminário de Arquitetura Latino Americana, Oaxtepec. Morelos. XI SAL: 2005.

ASHEIM, B.T. Industrial districts as "learning regions": a condition for prosperity.

European Planning Studies, vol. 4, n. 4, p. 379-400, 1996. 
BIANCHI, M. C. et al. (2010). Organisational modes for open innovation in the biopharmaceutical industry: an exploratory analysis. Technovation, v. 31, n. 1, p. 2233, 2010.

BUARQUE, S. C. Construindo o desenvolvimento local sustentável: metodologia e planejamento. Coleção Terra Mater. Rio de Janeiro: Garamond, 2002.

CAMPOS, I. M.; VALADARES, E. C. Disponível em www.schwartzman.org.br/simon/blog/inovacaomg.pdf. Acesso: abril de 2013.

CARRARO, A.; FONSECA, P. C. D. O desenvolvimento econômico no primeiro governo de Vargas (1930-1945). Anais...V Congresso Brasileiro de História Econômica e $6^{a}$ Conferência Internacional de História de Empresas, Caxambu, MG, 2003.

CHIARONI, D.; CHIESA, V.; FRATTINI, F. (2010). The open innovation journey: how firms dynamically implement the emerging innovation management paradigm.

Technovation, v. 31, n. 1, p. 34-43, 2010.

DINIZ, C. C. O papel das inovações e das instituições no desenvolvimento local. Anais... XXIX Encontro Nacional de Economia - ANPEC. Salvador, 2001.

DOSI, G. The nature of the innovative process. Pinter Publishers. Londres, 1998.

FERGUSON, R.; OLOFSSON, C. (2004). Science Parks and the development of NTBFs - Location, survival and growth. Journal of Technology Transfer, v. 29, n. 7, p 5-17, 2004.

FRANCO, A. Por que precisamos de desenvolvimento local integrado e sustentável. Brasília: Instituto de Política Millennium, 2000.

GALVÃO, O. J. A.; VERGOLINO, J. R. O. O comércio e a inserção competitiva do Nordeste no exterior e no Brasil. Fortaleza, CE: Banco do Nordeste do Brasil S.A., 2009.

GIL, A. C. Métodos e técnicas da pesquisa social. 5. ed. São Paulo: Atlas, 2006.

HAUSER, G; PALADINO, G. G.; MEDEIROS, L. A. Parques tecnológicos e meio urbano. Artigos e Debates. Brasília: Anprotec/SEBRAE, 1997.

HAUSER, G; ZEN, A.; LOPES, R. Parceria para o desenvolvimento regional: o caso do programa Porto Alegre Tecnópole - Brasil. Anais... Seminário Nacional de Parques Tecnológicos e Incubadoras de Empresas. Porto de Galinhas - Recife, 2004.

HINDLE, K.; YENCKEN, J. (2004). Public research commercialisation, entrepreneurship and new technology based firms: an integrated model.

Technovation, v. 24, n. 10, p. 793-803, 2004.

JOYAL, A. (2002). Le développement local - Comment stimuler l'économie des régions en difficulté. Les Éditions de I'IQRC, les Presses de l'Université laval, Quebec, 2002.

KEEBLE, D. et al. (1998). Collective learning processes and inter-firm networking in innovative high-technology regions. Working Paper Series, Cambridge, ESRC Centre for Business Research, University of Cambridge, march, 1998.

KIM, L.; NELSON, R. Tecnologia, aprendizado e inovação: as experiências das economias de industrialização recente. Campinas: Editora da Unicamp, 2005. 
LAKATOS, E. M.; MARCONI, M. A. Metodologia do trabalho científico. São Paulo: Atlas, 2001.

LLORENS, F. A. Desenvolvimento econômico local: caminhos e desafios para a construção de uma nova agenda política. 1. ed. Rio de Janeiro: BNDES, 2001.

OLIVEIRA, S. O. Desenvolvimento local e organização sócio-espacial. Revista Internacional de Desenvolvimento Local, vol. 4, n. 6, p. 47-53, 2003.

ORTT, J. R.; SMITS, R. (2006). Innovation management: different approaches to cope with the same trend. International Journal of Technology Management, $v$. 34 n. (3/4), p. 296-318, 2006.

SCHMOOKLER, J. Invention and economic growth. Harvard University Press, 1996.

SCHUMPETER, J. A. Teoria do desenvolvimento econômico. São Paulo: Nova cultural, 1997.

SICSÚ, A. B.; LIMA, J. P. R. Cadeias produtivas, cadeias do conhecimento e demandas tecnológicas no nordeste: análise de potencialidades e de estrangulamentos. Revista Análise Econômica, v. 21, n. 39, 2003.

SOUZA, N. J. de. Desenvolvimento econômico. 5. ed. São Paulo: Atlas, 2005.

STAINSACK, C. 2003. 113 f. Estruturação, organização, e gestão de incubadoras tecnológicas. (Dissertação de Mestrado). Programa de PósGraduação do Centro Federal de Educação Tecnológica do Paraná, Curitiba, 2003.

TAKAHASHI, S.; TAKAHASHI, V. P. Gestão de Inovação de Produtos: estratégia, processo, organização e conhecimento. Rio de Janeiro, Elsevier, 2007.

TIDD, J.; BESSANT, J.; PAVITT, K. Gestão da inovação. 3. ed. Porto Alegre, Bookman, 2008.

TIGRE, P. B. Gestão da inovação: a economia da tecnologia do Brasil. Rio de Janeiro: Elsevier, 2006.

VASCONCELOS, A. C. F. et al. Formas de atuação de empresas inseridas em redes de cooperação: um estudo exploratório em um consórcio de empresas de base tecnológica. Qu@litas Revista Eletrônica, v. 8, n. 2, p. 1-13, 2009.

ZOUAIN, D. M. 2003. 248 f. Parques tecnológicos: propondo um modelo conceitual para regiões urbanas - o parque tecnológico de São Paulo. (Tese de Doutorado). Instituto de Pesquisas Energéticas e Nucleares - Universidade de São Paulo, São Paulo, 2003.

ZOUAIN, D. M; PLONSKI, G. A. Parques Tecnológicos: planejamento e gestão. Brasília: ANPROTEC: SEBRAE, 140 p, 2006. 